\title{
Structure and thermal decomposition of ammonium metatungstate
}

\author{
Dávid Hunyadi $^{1}$, István Sajó ${ }^{2}$, Imre Miklós Szilágyi ${ }^{1,3, *}$ \\ ${ }^{1}$ Budapest University of Technology and Economics, Department of Inorganic and Analytical \\ Chemistry, H-1111 Budapest, Szt. Gellért tér 4. Hungary; \\ ${ }^{2}$ Environmental Analytical \& Geoanalytical Research Group, Szentágothai Research Centre, \\ University of Pécs, H-7624 Pécs, Ifjúság útja 20. Hungary; \\ ${ }^{3}$ Technical Analytical Chemistry Research Group of the Hungarian Academy of Sciences, H- \\ 1111 Budapest, Szt. Gellért tér 4. Hungary
}

Corresponding author: imre.szilagyi@mail.bme.hu

\section{Keywords}

Ammonium metatungstate, TG/DTA, MS, XRD, FTIR

\begin{abstract}
The structure, morphology of ammonium metatungstate (AMT), $\left(\mathrm{NH}_{4}\right)_{6}\left[\mathrm{H}_{2} \mathrm{~W}_{12} \mathrm{O}_{40}\right] \cdot 4 \mathrm{H}_{2} \mathrm{O}$ and its thermal decomposition in air and nitrogen atmospheres were investigated by SEM, FTIR, XRD and TG/DTA-MS. The cell parameters of the AMT sample were determined and refined with a full profile fit. The thermal decomposition of AMT involved several steps in inert atmosphere: (i) release of crystal water between $25-200{ }^{\circ} \mathrm{C}$ resulting in dehydrated AMT; (ii) formation of an amorphous phase between $200-380{ }^{\circ} \mathrm{C}$, (iii) from which hexagonal $\mathrm{WO}_{3}$ formed between $380-500{ }^{\circ} \mathrm{C}$, (iv) which then transformed into the more stable $\mathrm{m}-\mathrm{WO}_{3}$ between $500-600{ }^{\circ} \mathrm{C}$. As a difference in air, the as-formed $\mathrm{NH}_{3}$ ignited with an exothermic heat effect, and nitrous oxides formed as combustion products. The thermal behavior of AMT was similar to ammonium paratungstate (APT), $\left(\mathrm{NH}_{4}\right)_{10}\left[\mathrm{H}_{2} \mathrm{~W}_{12} \mathrm{O}_{42}\right] \cdot 4 \mathrm{H}_{2} \mathrm{O}$, the only main difference being the lack of dry $\mathrm{NH}_{3}$ evolution between $170-240{ }^{\circ} \mathrm{C}$ in the case of AMT.
\end{abstract}

\section{Introduction}


Ammonium tungstates are important members of isopolytungstates. They have three forms, i.e. ammonium paratungstate (APT), $\left(\mathrm{NH}_{4}\right)_{10}\left[\mathrm{H}_{2} \mathrm{~W}_{12} \mathrm{O}_{42}\right] \cdot \mathrm{xH}_{2} \mathrm{O} \quad(\mathrm{X}=4,7,10)$; ammonium metatungstate (AMT), $\left(\mathrm{NH}_{4}\right)_{6}\left[\mathrm{H}_{2} \mathrm{~W}_{12} \mathrm{O}_{40}\right] \cdot \mathrm{nH}_{2} \mathrm{O}(\mathrm{n}=1-22)$; and ammonium orthotungstate (AT), $\left(\mathrm{NH}_{4}\right)_{2} \mathrm{WO}_{4}$ [1]. One of their major applications is that tungsten oxides, metal tungstates, tungsten carbides or tungsten metal can be prepared from them, all of which are significant for various industries. Tungsten oxides can be used as catalysts [2-5], photocatalysts [6-10], gas sensors [11-18], chromogenic materials [19-21]; metal tungstates can be used among others as catalysts [22], pigments [23,24]; tungsten carbides are the hard components in cutting, drilling, tools [25-27] and they are also used as catalysts [28,29]; while tungsten metal is a key element in lighting industry [1,30-34].

The industrial preparation of tungsten oxides, tungsten carbides and tungsten metal is mostly based on thermal decomposition (oxidation or reduction) of ammonium tungstates. Among ammonium tungstates, only the thermal behavior of APT was studied in detail in the past decades, which is mostly explained by that APT with is well defined preparation route and structure is the starting material of tungsten manufacture $[1,32,33]$. In contrast, to the best of our knowledge, the thermal decomposition of AMT and AT has not been investigated in detail. This is unexpected, especially in the case of AMT, as it is the most water soluble ammonium tungstate, and AMT is widely used to prepare various tungsten oxide nanostructures by annealing [35,36].

In the case of AMT, not only its thermal decomposition sequence, but also is structure and composition are not straightforward. According to Christian and Wittingham [37] as well as Fait et al [38], depending on its crystal water content AMT can have three different cubic unit cells, however, only of them, the AMT $22 \mathrm{H}_{2} \mathrm{O}$ has an XRD reference card (PDF 00-0390168). There exists a fourth, anorthic AMT structure (PDF 04-012-6600) as well. In addition, commercial AMT can be obtained with different CAS numbers (e.g. 12333-11-8, 402568-096, 12028-48-7), to which different compositions are assigned, i.e. $\left(\mathrm{NH}_{4}\right)_{6}\left[\mathrm{H}_{2} \mathrm{~W}_{12} \mathrm{O}_{40}\right] \cdot \mathrm{nH}_{2} \mathrm{O}$ or $\left(\mathrm{NH}_{4}\right)_{6}\left[\mathrm{~W}_{12} \mathrm{O}_{39}\right] \cdot \mathrm{yH}_{2} \mathrm{O}$.

In the presents study, we aimed to get more information on the structure of AMT and intended to characterize its thermal decomposition. In addition, we compared the structure and thermal behavior of the commercially available AMT products. To achieve these, we studied the structure and morphology of the AMT materials and compared their thermal decomposition by scanning electron microscopy (SEM), Fourier transform infrared spectroscopy (FTIR), 
powder X-ray diffraction (XRD) and thermal analysis (TG/DTA-MS) in inert $\left(\mathrm{N}_{2}\right)$ and in oxidizing (air) atmospheres.

\section{Experimental}

Two ammonium metatungstate samples were obtained from Sigma-Aldrich with compositions of $\left(\mathrm{NH}_{4}\right)_{6}\left[\mathrm{H}_{2} \mathrm{~W}_{12} \mathrm{O}_{40}\right] \cdot \mathrm{nH}_{2} \mathrm{O}(\mathrm{CAS}: 12333-11-8)$ and $\left(\mathrm{NH}_{4}\right)_{6}\left[\mathrm{~W}_{12} \mathrm{O}_{39}\right] \cdot \mathrm{yH}_{2} \mathrm{O}(\mathrm{CAS} 402568-09$ 6), and they were named AMT1 and AMT2, respectively.

SEM images were obtained by a JEOL JSM-5500LV scanning electron microscope.

Powder XRD patterns were recorded on a PANalytical X'pert Pro MPD X-ray diffractometer using $\mathrm{Cu} \mathrm{K}_{\alpha}$ radiation.

FTIR spectra were measured by an Excalibur Series FTS 3000 (Biorad) FTIR spectrophotometer in the range of $400-4000 \mathrm{~cm}^{-1}$ in $\mathrm{KBr}$ pellets.

TG/DTA measurements were performed on an STD 2960 Simultaneous DTA/TGA (TA Instruments Inc.) thermal analyzer using a heating rate of $10{ }^{\circ} \mathrm{C} \mathrm{min}^{-1}$ and $\mathrm{Pt}$ crucibles. The reactor was purged either with air or nitrogen atmospheres $\left(130 \mathrm{ml} \mathrm{min}{ }^{-1}\right)$. Evolved gas analytical (EGA) curves were recorded by a Thermostar GSD 200 (Balzers Instruments) quadruple mass spectrometer (MS). A mass range between $\mathrm{m} / \mathrm{z}=1-64$ was monitored through 64 channels in Multiple Ion Detection Mode (MID) with a measuring time of $0.5 \mathrm{~s} \mathrm{channel}^{-1}$. Further details of the TG/DTA-MS setup are described elsewhere [39,40].

\section{Results and discussion}

\section{Characterization of AMT1}

According to SEM images (Fig. 1a), AMT1 consisted of ca. 5-50 $\mu \mathrm{m}$ microspheres. Many such spheres were cracked, and the empty inner part of the spheres could be seen, showing that AMT1 was actually built up by hollow microspheres. In the voids of cracked larger spheres, even smaller spheres could be seen, which could get inside most probably after the cracking occurred.

In the FTIR spectrum of AMT1 (Fig. 2a), the O-H deformation and stretching vibrations of water molecules in AMT were present around $1630 \mathrm{~cm}^{-1}$ and $3570 \mathrm{~cm}^{-1}$, while the N-H deformation and stretching vibrations of $\mathrm{NH}_{4}{ }^{+}$ions were visible at $1400 \mathrm{~cm}^{-1}$ and $3135 \mathrm{~cm}^{-1}$. The peaks belonging to the metatungstate ion were observable mostly below $1000 \mathrm{~cm}^{-1}$, 
which could be identified based on the FTIR data of pure polytungstates, AMT composites and $\mathrm{WO}_{3}$ [36,41-45], as the FTIR spectrum of AMT has not been published previously. Hence, bands at about $940 \mathrm{~cm}^{-1}\left(930,955 \mathrm{~cm}^{-1}\right)$ were assigned to $\mathrm{W}=\mathrm{O}$ vibrations, while the peaks at $700-900 \mathrm{~cm}^{-1}\left(785,882 \mathrm{~cm}^{-1}\right)$ were explained by the $\mathrm{W}-\mathrm{O}$ vibrations.

The XRD spectrum of AMT1 does not resemble to any of the published XRD data about AMT [37,38] or the available XRD reference cards of AMT (PDF 00-039-0168 and 04-0126600). Thus, using Si internal standard we determined the cell parameters of our AMT sample, and refined them with full profile fit. The unit cell of the AMT sample was identified to be orthorhombic $\left(\alpha=\beta=\gamma=90^{\circ}\right)$ with space group Pcca [Nr. 54]. The obtained values for the $a, b, c$ cell parameters were $33.438,17.425,14.112 \AA$, respectively, the cell volume was calculated to be $8222.458 \AA^{3}$, the value of $Z$ was 8 , and the calculated density was $4.863 \mathrm{~g} \mathrm{~cm}^{-}$

${ }^{3}$. The formula of the AMT sample was determined as $\left(\mathrm{NH}_{4}\right)_{6}\left[\mathrm{H}_{2} \mathrm{~W}_{12} \mathrm{O}_{40}\right] \cdot 4 \mathrm{H}_{2} \mathrm{O}$ by TG data (see later). We present the indexed reflections of the AMT1 sample obtained after full profile fit in Table 1, so that they can be used later as a reference.

\section{Thermal decomposition of AMT1 in nitrogen}

The first decomposition step (Fig. 4) occurred between $25-200{ }^{\circ} \mathrm{C}$, and it was accompanied by an endothermic heat effect. Here, the crystal water content of ammonium metatungstate evolved, as evidenced by the MS ion current curve of $\mathrm{H}_{2} \mathrm{O}$. The water release happened in two overlapping processes (endothermic DTA peaks at 114 and $139{ }^{\circ} \mathrm{C}$ ). These correspond altogether to the loss of 4 crystal water molecules $(1.6 \%$ and $0.8 \%$ mass losses in the first and second processes, respectively, match the release of ca. 2.7 and 1.3 water molecules). Parallel to this, in the infrared spectrum the intensity of water peaks at $1630 \mathrm{~cm}^{-1}$ and 3570 $\mathrm{cm}^{-1}$ were slightly decreased (Fig. 2a). The W-O bonds in the solid phase did not change according to infrared spectra. Though, based on this, most probably the metatungstate ion remained intact, the loss of crystal water changed the overall structure of AMT, as the XRD pattern contained much less reflections at $200{ }^{\circ} \mathrm{C}$ (Fig. 3a). We could not identify the exact crystal structure at $200^{\circ} \mathrm{C}$ with XRD.

In the second decomposition step $\left(250-380^{\circ} \mathrm{C}\right)$ in an endothermic reaction most $\mathrm{NH}_{4}{ }^{+}$ions were removed from the structure, and thus $\mathrm{NH}_{3}$ and $\mathrm{H}_{2} \mathrm{O}$ were released (Fig. 4). Accordingly, in the infrared spectrum the intensity of water peaks at $1630 \mathrm{~cm}^{-1}$ and $3570 \mathrm{~cm}^{-1}$ and of $\mathrm{NH}_{4}^{+}$ peaks at $1400 \mathrm{~cm}^{-1}$ and $3135 \mathrm{~cm}^{-1}$ greatly decreased. The vibrations in the $\mathrm{W}-\mathrm{O}$ bond region below $1000 \mathrm{~cm}^{-1}$ altered significantly (Fig. 2). At $380{ }^{\circ} \mathrm{C}$ the XRD pattern shows an 
amorphous phase (Fig. 3). This is explained by that when the $\mathrm{NH}_{4}{ }^{+}$ions were removed, the structure of AMT collapsed, and the metatungstate ions, which had been separated previously by $\mathrm{NH}_{4}{ }^{+}$ions, got connected. Consequently, the $\mathrm{WO}_{6}$ octahedra building up the metatungstate ions changed their position and orientation, and this lead to the formation of an intermediate amorphous phase.

In the third decomposition step $\left(380-500{ }^{\circ} \mathrm{C}\right) \mathrm{H}_{2} \mathrm{O}$ and $\mathrm{NH}_{3}$ were released (Fig. 4). In the infrared spectrum the peaks of water at $1630 \mathrm{~cm}^{-1}$ and $3570 \mathrm{~cm}^{-1}$ and of $\mathrm{NH}_{4}^{+}$at $1400 \mathrm{~cm}^{-1}$ and $3135 \mathrm{~cm}^{-1}$ almost completely disappeared (Fig. 2). In this step hexagonal (h-) $\mathrm{WO}_{3}$ (PDF 33-1387) crystallized from the amorphous phase, accompanied by an exothermic heat effect with a maximum at $421^{\circ} \mathrm{C}$ on the DTA curve (Fig. 4).

In the fourth step (500-600 ${ }^{\circ} \mathrm{C}$ ) only a small mass loss occurred and tiny amount of water evolved. When the water evolution ended, the metastable $\mathrm{h}-\mathrm{WO}_{3}$ transformed in an exothermic reaction (DTA peak at $548{ }^{\circ} \mathrm{C}$ ) into the stable monoclinic (m-) modification of $\mathrm{WO}_{3}$ (PDF 89-4476) [46].

The final mass of the decomposition residue (92.0 mass\%) matched well the theoretical value (91.9 mass\%) for decomposing $\left(\mathrm{NH}_{4}\right)_{6}\left[\mathrm{H}_{2} \mathrm{~W}_{12} \mathrm{O}_{40}\right] \cdot 4 \mathrm{H}_{2} \mathrm{O}$ into $\mathrm{WO}_{3}$, thus TG data confirmed the composition of AMT1.

\section{Thermal decomposition of AMT1 in air}

In the first decomposition step, there was no difference between the thermal behavior of AMT in air and inert atmospheres (Figs. 5-7). The oxidizing effect of air made a difference only above $250{ }^{\circ} \mathrm{C}$, when the as-released $\mathrm{NH}_{3}$ started to burn into nitrous oxides, catalyzed by the Pt crucible and/or the as-formed tungsten oxide structure. Among the combustion products of $\mathrm{NH}_{3}$, the formation of $\mathrm{N}_{2} \mathrm{O}$ is favored below $400{ }^{\circ} \mathrm{C}$, while $\mathrm{NO}$ forms rather above this temperature [47]. This is clearly shown by the intensity changes in the MS curves of the two gases in the second and third decomposition steps. The combustion of $\mathrm{NH}_{3}$ is an exothermic reaction, and the generated heat made the DTA peak turn into slightly exothermic $\left(365^{\circ} \mathrm{C}\right)$ at the end of the second decomposition step. In the third decomposition step the exothermic heat effects of the $\mathrm{h}-\mathrm{WO}_{3} / \mathrm{m}-\mathrm{WO}_{3}$ transformation $\left(419{ }^{\circ} \mathrm{C}\right)$ and of the $\mathrm{NH}_{3}$ ignition $\left(441{ }^{\circ} \mathrm{C}\right)$ were added, and thus the DTA peak between $400-450{ }^{\circ} \mathrm{C}$ was much sharper in air than in nitrogen. In air there were no significant differences in the FTIR patterns, compared to nitrogen. In contrast, the XRD pattern recorded in air at $200{ }^{\circ} \mathrm{C}$ differed significantly and contained more reflections than in inert atmosphere. Another change in air was that at $500{ }^{\circ} \mathrm{C}$ the sample 
already contained considerable amount of $\mathrm{m}-\mathrm{WO}_{3}$ besides $\mathrm{h}-\mathrm{WO}_{3}$. As a result, the exothermic DTA peak above $500{ }^{\circ} \mathrm{C}$ was much smaller.

\section{Comparison of the morphology, structure and thermal behavior of AMT1 and AMT2}

AMT1 and AMT2 differed in their morphology. While AMT1 was built up by 5-50 $\mu \mathrm{m}$ hollow microspheres, AMT2 consisted of 2-10 $\mu \mathrm{m}$ particles, and most of them were aggregated into larger, 10-100 $\mu \mathrm{m}$ blocks.

In contrast to the different morphologies, both FTIR spectra and the XRD patterns of AMT1 and AMT2 were identical. In the FTIR spectra the positions and intensities of the W-O, O-H and N-H bands were the same for both AMT1 and AMT2. Similarly, the $2 \theta$ values and relative intensities of the XRD reflections were also identical in the case of the two AMT materials, and AMT2 had the same unit cell as AMT1.

The TG/DTA curves of AMT2 (Fig. 8) were not just similar to AMT1, but basically identical with it. The residual masses for AMT1 and AMT2 in the first, second and third decomposition steps were almost the same, i.e. 97.6 and $97.6 \%$; 93.5 and $93.4 \% ; 92.0$ and $91.9 \%$, respectively.

The final mass of the decomposition residue (91.9 mass\%) matched the theoretical value (91.9 mass\%) for decomposing $\left(\mathrm{NH}_{4}\right)_{6}\left[\mathrm{H}_{2} \mathrm{~W}_{12} \mathrm{O}_{40}\right] \cdot 4 \mathrm{H}_{2} \mathrm{O}$ into $\mathrm{WO}_{3}$, and not that of $\left(\mathrm{NH}_{4}\right)_{6}\left[\mathrm{~W}_{12} \mathrm{O}_{39}\right] \cdot 4 \mathrm{H}_{2} \mathrm{O}(92.4$ mass \%). Therefore, TG/DTA data also supported that AMT2 was identical with AMT1, and its composition was not $\left(\mathrm{NH}_{4}\right)_{6}\left[\mathrm{~W}_{12} \mathrm{O}_{39}\right] \cdot 4 \mathrm{H}_{2} \mathrm{O}$, as provided by its manufacturer, but $\left(\mathrm{NH}_{4}\right)_{6}\left[\mathrm{H}_{2} \mathrm{~W}_{12} \mathrm{O}_{40}\right] \cdot 4 \mathrm{H}_{2} \mathrm{O}$.

\section{Comparison of the thermal behavior of AMT and APT}

Previously AMT [1,33,38,47-52] or a structure close to AMT [38] was said to be a decomposition product of APT at $240{ }^{\circ} \mathrm{C}$. Based on these, it was unknown whether the decomposition of AMT would be the same as the decomposition of APT above $240{ }^{\circ} \mathrm{C}$, or it would differ significantly.

The decomposition of APT includes several steps [1,33,38,47-52]. In inert atmosphere until ca. $170{ }^{\circ} \mathrm{C}$ APT loses its crystal water content in an endothermic reaction. Then in the second decomposition step between ca. $170-240{ }^{\circ} \mathrm{C}$, dry $\mathrm{NH}_{3}$ is released, accompanied by an endothermic heat effect. It was at this point, that previously AMT was reported to form, while 
recently it was shown that the intermediate decomposition product of APT here is an ammonium hydrogen paratungstate with the ideal composition of $\left(\mathrm{NH}_{4}\right)_{6} \mathrm{H}_{4}\left[\mathrm{H}_{2} \mathrm{~W}_{12} \mathrm{O}_{42}\right]$, from which AMT can be produced by digesting the intermediate by hot water [38]. Then between 240-370 ${ }^{\circ} \mathrm{C}$ both $\mathrm{NH}_{3}$ and $\mathrm{H}_{2} \mathrm{O}$ are released, and an amorphous phase forms in an endothermic reaction. Between $370-450{ }^{\circ} \mathrm{C}$ from this phase hexagonal ammonium tungsten bronze (HATB), $\left(\mathrm{NH}_{4}\right)_{0.33-\mathrm{x}} \mathrm{WO}_{3-\mathrm{y}}$ or $\mathrm{h}-\mathrm{WO}_{3}$ forms. It is noted that there is no sharp division line between $\mathrm{h}-\mathrm{WO}_{3}$ and HATB. The difference between these two phases is caused mostly by the more oxidized state of tungsten atoms in $\mathrm{h}-\mathrm{WO}_{3}$ and also by the lower occupancy of the hexagonal channels in the case of $\mathrm{h}-\mathrm{WO}_{3}[53,54]$. Between $500-600{ }^{\circ} \mathrm{C}$ the as-formed $\mathrm{HATB} / \mathrm{h}-\mathrm{WO}_{3}$ then transforms in an exothermic reaction to the more stable monoclinic tungsten oxide. In air, the decomposition sequence of APT is quite similar. In the oxidizing atmosphere, as a difference the as-released $\mathrm{NH}_{3}$ starts to burn above $250-300{ }^{\circ} \mathrm{C}$, changing the DTA peaks into exothermic. The exothermic formation of $\mathrm{m}-\mathrm{WO}_{3}$ takes place at $50{ }^{\circ} \mathrm{C}$ lower temperature in air than in inert atmosphere.

Our results have shown that below $170-200{ }^{\circ} \mathrm{C}$, similarly APT, AMT lost its crystal water content. A clear difference was that while between $170-240{ }^{\circ} \mathrm{C}$ dry $\mathrm{NH}_{3}$ is released from APT, no dry $\mathrm{NH}_{3}$ evolution was observed in the case of AMT in this temperature region. The collapse of the starting crystal structure and the formation of an amorphous phase between 250-380 ${ }^{\circ} \mathrm{C}$ were similar in the case of the two materials. The exothermic crystallization of $\mathrm{HATB} / \mathrm{h}-\mathrm{WO}_{3}$ and its exothermic transformation into $\mathrm{m}-\mathrm{WO}_{3}$ at elevated temperatures was also similar.

To conclude, the thermal decompositions of APT and AMT are similar; the main difference is that the release of dry $\mathrm{NH}_{3}$ between $170-240{ }^{\circ} \mathrm{C}$ does not take place in the case of AMT.

\section{Conclusions}

We have studied the structure, morphology and thermal decomposition of two commercially available ammonium metatungstate (AMT1 and AMT2) materials by SEM, FTIR, XRD and TG/DTA-MS. The need for our research was that there had been no previous studies on the thermal behavior of AMT.

The cell parameters of the AMT1 sample were determined, and its XRD reflections were indexed after full profile fit. It was found, that the XRD patterns and FTIR spectra of both AMT materials, which had different CAS numbers, were basically the same. The samples only differed in their morphology. 
The thermal decomposition of AMT involved several steps in inert atmosphere: (i) release of crystal water to get dehydrated AMT between $25-200{ }^{\circ} \mathrm{C}$; (ii) formation of an amorphous phase between $200-380{ }^{\circ} \mathrm{C}$, from which (iii) hexagonal $\mathrm{WO}_{3}$ formed between $380-500{ }^{\circ} \mathrm{C}$, which then transformed into the more stable $\mathrm{m}-\mathrm{WO}_{3}$ between $500-600{ }^{\circ} \mathrm{C}$. As a difference compared to inert atmosphere, in air the as-formed $\mathrm{NH}_{3}$ ignited with an exothermic heat effect.

Similar to their XRD patterns and FTIR spectra, the two AMT materials had identical thermal decomposition courses as well. Thermal data confirmed that both AMT1 and AM2 had the formula $\left(\mathrm{NH}_{4}\right)_{6}\left[\mathrm{H}_{2} \mathrm{~W}_{12} \mathrm{O}_{40}\right] \cdot 4 \mathrm{H}_{2} \mathrm{O}$.

The thermal behavior of AMT resembled to the widely studied APT. The main difference between them was the lack of dry $\mathrm{NH}_{3}$ evolution between $170-240{ }^{\circ} \mathrm{C}$ in the case of AMT.

\section{Acknowledgements}

I. M. S. thanks for a János Bolyai Research Fellowship of the Hungarian Academy of Sciences and an OTKA-PD-109129 grant.

\section{References}

[1] Lassner E, Schubert WD. Tungsten properties, chemistry, technology of the element, alloys, and chemical compounds. New York: Kluwer Academic/Plenum Publishers; 1999.

[2] Hammond C, Straus J, Righettoni M, Pratsinis SE, Hermans I. Nanoparticulate tungsten oxide for catalytic epoxidations. ACS Catal. 2013;3:321-7.

[3] Di Valentin C, Wang F, Pacchioni G. Tungsten oxide in catalysis and photocatalysis: Hints from DFT. Topics Catal. 2013;56:1404-19.

[4] Veith GM, Lupini AR, Pennycook SJ, Alberto V, Prati L, Dudney NJ. Magnetron sputtering of gold nanoparticles onto $\mathrm{WO}_{3}$ and activated carbon. Catal Today 2007;122:248-53.

[5] Phuruangrat A, Ham DJ, Hong SJ, Thongtem S, Lee JS. Synthesis of hexagonal $\mathrm{WO}_{3}$ nanowires by microwave-assisted hydrothermal method and their electrocatalytic activities for hydrogen evolution reaction. J Mater Chem. 2010;20:1683-90. 
[6] Szilágyi IM, Fórizs B, Rosseler O, Szegedi Á, Németh P, Király P, Tárkányi G, Vajna B, Varga-Josepovits K, László K, Tóth AL, Baranyai P, Leskelä M. $\mathrm{WO}_{3}$ photocatalysts: influence of structure and composition. J Catal. 2012;294:119-27.

[7] Lin CT, Tsai TH. Solution volume effect of photodegradation by $1-\mathrm{D} \mathrm{WO}_{3}$ nanorods via microwave-assisted solvothermal heating under the UV irradiation. Asian J Chem. 2013;25:7098-102.

[8] Nandiyanto ABD, Arutanti O, Ogi T, Iskandar F, Kim TO, Okuyama K. Synthesis of spherical macroporous $\mathrm{WO}_{3}$ particles and their high photocatalytic performance. Chem Eng Sci. 2013;101:523-32.

[9] Liu BX, Wang JS, Li HY, Wu JS, Zhou ML, Zuo TY. Facile synthesis of hierarchical hollow mesoporous $\mathrm{Ag} / \mathrm{WO}_{3}$ spheres with high photocatalytic performance. J Nanosci Nanotech. 2013;13:4117-22.

[10] Karacsonyi E, Baia L, Dombi A, Danciu V, Mogyorosi K, Pop LC, Kovacs G, Cosoveanu V, Vulpoi A, Simon S, Pap Z. The photocatalytic activity of $\mathrm{TiO} 2 / \mathrm{WO}_{3} /$ noble metal ( $\mathrm{Au}$ or $\mathrm{Pt}$ ) nanoarchitectures obtained by selective photodeposition. Catal Today 2013;208:19-27.

[11] Szilágyi IM, Saukko S, Mizsei J, Tóth AL, Madarász J, Pokol G. Gas sensing selectivity of hexagonal and monoclinic $\mathrm{WO}_{3}$ to $\mathrm{H}_{2} \mathrm{~S}$. Solid State Sci. 2010;12:1857-60.

[12] Szilágyi IM, Wang L, Gouma PI, Balázsi C, Madarász J, Pokol G. Preparation of hexagonal $\mathrm{WO}_{3}$ from hexagonal ammonium tungsten bronze for sensing $\mathrm{NH}_{3}$. Mater Res Bull. 2009;44:505-8.

[13] Balázsi C, Wang L, Zayim EO, Szilágyi IM, Sedlackova K, Pfeifer J, Tóth AL, Gouma PI. Nanosize hexagonal tungsten oxide for gas sensing applications. J Eur Ceram Soc. 2008;28:913-7.

[14] Szilágyi IM, Saukko S, Mizsei J, Király P, Tárkányi G, Tóth AL, Szabó A, VargaJosepovits K, Madarász J, Pokol G. Controlling the composition of nanosize hexagonal $\mathrm{WO}_{3}$ for gas sensing. Mater Sci Forum 2008;589:161-5.

[15] Wang L, Pfeifer J, Balázsi C, Szilágyi IM, Gouma PI. Nanostructured hexagonal tungsten oxides for ammonia sensing. Proceedings of SPIE - The International Society for Optical Engineering "Nanosensing: Materials, Devices, and Systems III. 2007,6769:67690E.

[16] Balázsi C, Sedlackova K, Pfeifer J, Tóth AL, Zayim EA, Szilágyi IM, Wang LS, Kalyanasundaram K, Gouma PI. Synthesis and examination of hexagonal Tungsten oxide nanocrystals for electrochromic and sensing applications. NATO Science for 
Peace and Security Series C: Environmental Security; Sensors for Environment, Health and Security. 2009:77-91.

[17] Kukkola J, Mohl M, Leino AR, Maklin J, Halonen N, Shchukarev A, Konya Z, Jantunen H, Kordas K. Room temperature hydrogen sensors based on metal decorated $\mathrm{WO}_{3}$ nanowires. Sens Actuat B. 2013;186:90-5.

[18] Zhang YD, He WW, Zhao HX, Li PJ. Template-free to fabricate highly sensitive and selective acetone gas sensor based on $\mathrm{WO}_{3}$ microspheres. Vacuum. 2013;95:30-4.

[19] Chromčíková M, Liška M, Lissová M, Mošner P, Koudelka L. Structural relaxation of $\mathrm{PbO}-\mathrm{WO}_{3}-\mathrm{P}_{2} \mathrm{O}_{5}$ glasses. J Therm Anal Calorim. 2013;114:947-54.

[20] Shen Y, Zhu H, Huang R, Zhao L, Yan SN. Synthesis and photochromic properties of $\mathrm{WO}_{3}$ powder induced by oxalic acid. Sci China Ser B-Chem. 2009;52:609-14.

[21] Cai GF, Zhou D, Xiong QQ, Zhang JH, Wang XL, Gu CD, Tu JP. Efficient electroctrochromic materials based on $\mathrm{TiO}_{2} @ \mathrm{WO}_{3}$ core/shell nanorod arrays. Solar En Mater Solar Cell. 2013;117:231-8.

[22] Hongjie L, Zhang L. An overview on synthetic methods of benzyl acetate. Eur Chem Bull. 2013;2:272-4.

[23] Blovská V, Bělina P, Šulcová P. Synthesis of tungstate pigments of the formula $\mathrm{MNd}_{2} \mathrm{~W}_{2} \mathrm{O}_{10}(\mathrm{M}=\mathrm{Ni}, \mathrm{Zn}, \mathrm{Mn})$. J Therm Anal Calorim. 2013;113:83-9.

[24] Łącz A, Pasierb P. Synthesis and properties of $\mathrm{BaCe}_{1-\mathrm{x}} \mathrm{Y}_{\mathrm{x}} \mathrm{O}_{3-\delta}-\mathrm{BaWO}_{4}$ composite protonic conductors. J Therm Anal Calorim. 2013;113: 405-12.

[25] Biedunkiewicz A, Szymczyk A, Chrosciechowska J. Oxidation of (Ti,W)C ceramic powders. J Therm Anal Calorim. 2004;77:75-83.

[26] Kano S, Inoue T. Surface softening and hardening of WC-Co using pulsed laser irradiation. Surf Coat Tech. 2006;201:223-9.

[27] Kim HC, Shon IJ, Yoon JK, Doh JM. Consolidation of ultra fine WC and WC-Co hard materials by pulsed current activated sintering and its mechanical properties. Int $\mathbf{J}$ Refract Metal Hard Mater. 2007;25:46-52.

[28] Moreno-Castilla C, Alvarez-Merino MA, Carrasco-Marín F, Fierro JLG. Tungsten and tungsten carbide supported on activated carbon: surface structures and performance for ethylene hydrogenation. Langmuir 2001;17:1752-6.

[29] Szymańska-Kolasa A, Lewandowski M, Sayag C, Djéga-Mariadassou G. Comparions of molybdenum carbide for the hydrodesulfurization of dibenzithiophene. CatalToday. 2007;119:7-12. 
[30] Szilágyi IM, Madarász J, Pokol G, Hange F, Szalontai G, Varga-Josepovits K, Tóth AL. The effect of $\mathrm{K}^{+}$ion doping on the structure and thermal reduction of hexagonal ammonium tungsten bronze. J Therm Anal Calorim. 2009;97:11-8.

[31] Bartha L, Neugebauer J. Aspects of Effective Doping and the Incorporation of Dopant. Int J Refract Metal Hard Mater. 1995;13:1-34.

[32] Pink E, Bartha L. The Metallurgy of Doped/Non-Sag Tunsgten. London: Elsevier; 1989.

[33] van Put JW. Crystallisation and Processing of Ammonium Paratungstate (APT). Int J Refract Metal Hard Mater. 1995;13:61-76.

[34] Bartha L, Kiss BA, Szalay T. Chemistry of tungsten oxide bronzes. Int J Refract Metal Hard Mater. 1995;13:77-91.

[35] Szilágyi IM, Santala E, Heikkilä M, Pore V, Kemell M, Teucher G, Firkala T, Färm E, Nikitin T, Khriachtchev L, Räsänen M, Ritala M, Leskelä M. Photocatalytic properties of $\mathrm{WO}_{3} / \mathrm{TiO}_{2}$ core-shell nanofibers prepared by electrospinning and atomic layer deposition. Chem Vapor Dep. 2013;19:149-55.

[36] Szilágyi IM, Santala E, Heikkilä M, Kemell M, Nikitin T, Khriachtchev L, Räsänen M, Ritala M, Leskelä M. Thermal study on electrospun polyvinylpyrrolidone/ammonium metatungtate nanofibers: Optimising the annealing conditions for obtaining $\mathrm{WO}_{3}$ nanofibers. J Therm Anal Calorim. 2011;105:73-81.

[37] Christian JB, Whittingham MS. Structural study of ammonium metatungstate. J Solid State Chem. 2008;181:1782-91.

[38] Fait MJG, Lunk HJ, Feist M, Schneider M, Dann JN, Frisk TA. Thermal decomposition of ammonium paratungstate tetrahydrate under non-reducing conditions

Characterization by thermal analysis, X-ray diffraction and spectroscopic methods. Thermochim Acta. 2008;469:12-22.

[39] Prasad RL, Kushwaha A, Szilágyi IM, Kótai L. Solid state thermal degradation behaviour of 1-D coordination polymers of $\mathrm{Ni}(\mathrm{II})$ and $\mathrm{Cu}(\mathrm{II})$ bridged by conjugated ligand. J Therm Anal Calorim. 2013;114:653-64.

[40] Szilágyi IM, Deák A, Várhelyi jr. C, Madarász J, Pokol G, Gömöry Á, Várhelyi C. Structural and thermal study of assymetric $\alpha$-dioxime complexes of $\mathrm{Co}$ (III) with $\mathrm{Cl}$ and methyl-pyridines. Polyhedron. 2010;10:2185-9.

[41] Zhang HY, Xu L, Wang EB, Jiang M, Wu AG, Li Z. Photochromic behavior and luminescent properties of novel hybrid organic-inorganic film doped with Preyssler's 
heteropoly acid $\mathrm{H}_{12}\left[\mathrm{EuP}_{5} \mathrm{~W}_{30} \mathrm{O}_{110}\right]$ and polyvinylpyrrolidone. Mater Lett. 2003;57:141722.

[42] Li Y, Li YG, Zhang ZM, Wu Q, Wang EB. A new polyoxotungstate-based $\left\{\mathrm{W}_{72} \mathrm{~V}_{30}\right\}$ spherical cage. Inorg Chem Commun. 2009;12:864-7.

[43] Duplyakin VK, Baklanova ON, Chirkova OA, Antonicheva NV, Arbuzov AB, Voitenko NN, Drozdov VA, Likholobov VA. Interaction of nickel hydroxocarbonate, ammonium paramolybdate, and ammonium metatungstate under mechanical activation. Kin Catal. 2010;51:126-30.

[44] Sunita G, Devassy BM, Vinu A, Sawant DP, Balasubramanian VV, Halligudi SB. Synthesis of biodiesel over zirconia-supported isopoly and heteropoly tungstate catalysts. Catal Commun. 2008;9:696-702.

[45] Sarish S, Devassy BM, Böhringer W, Feltcher J, Halligudi SB. Liquid-phase alkylation of phenol with long-chain olefins over $\mathrm{WO}_{\mathrm{x}} / \mathrm{ZrO}_{2}$ solid acid catalysts. J Mol Catal A. 2005;240:123-31.

[46] Szilágyi IM, Pfeifer J, Balázsi C, Tóth AL, Varga-Josepovits K, Madarász J, Pokol G. Thermal stability of hexagonal tungsten trioxide. J Therm Anal Calorim. 2008;94:499505.

[47] Madarász J, Szilágyi IM, Hange F, Pokol G. Comparative evolved gas analyses (TGFTIR, TG/DTA-MS) and solid state (FTIR, XRD) studies on thermal decomposition of ammonium paratungstate tetrahydrate (APT) in air. J Anal Appl Pyrol. 2004;72:197201.

[48] Mansour SAA, Mohamed MA. Thermal decomposition and the creation of reactive solid surfaces. $\mathrm{V}$. The genesis course of the $\mathrm{WO}_{3}$ catalyst from its ammonium paratungstate precursor. Thermochim Acta. 1988;129:187-96.

[49] French GJ; F R Sale. A re-investigation of the thermal decomposition of ammonium paratungstate. J Mater Sci. 1981;16:3427-36.

[50] Szilágyi IM, Madarász J, Hange F, Pokol G. On-line evolved gas analyses (EGA by TG-FTIR and TG/DTA-MS) and solid state (FTIR, XRD) studies on thermal decomposition and partial reduction of ammonium paratungstate tetrahydrate. Solid State Ionics. 2004;172:583-6.

[51] Szilágyi IM, Madarász J, Hange F, Pokol G. Partial thermal reduction of ammonium paratungstate tetrahydrate. J Therm Anal Calorim. 2007;88:139-44. 
[52] Szilágyi IM, Hange F, Madarász J, Pokol G. In situ HT-XRD study on the formation of hexagonal ammonium tungsten bronze by partial reduction of ammonium paratungstate tetrahydrate. Eur J Inorg Chem. 2006;17:3413-18.

[53] Szilágyi IM, Sakó I, Király P, Tárkányi G, Tóth AL, Szabó A, Varga-Josepovits K, Madarász J, Pokol G. Phase transformations of ammonium tungsten bronzes. J Therm Anal Calorim. 2009;98:707-16.

[54] Szilágyi IM, Madarász J, Király P, Tárkányi G, Tóth AL, Szabó A, Varga-Josepovits K, Pokol G. Stability and controlled composition of hexagonal $\mathrm{WO}_{3}$. Chem Mater. 2008;20:4116-25.

\section{Tables}

Table 1. Powder XRD data of ammonium metatungstate hydrate, $\left(\mathrm{NH}_{4}\right)_{6}\left[\mathrm{H}_{2} \mathrm{~W}_{12} \mathrm{O}_{40}\right] 4 \mathrm{H}_{2} \mathrm{O}$ obtained after full profile fit $\left(\mathrm{LOI}(\mathrm{c})=7.86\right.$; Orthorhombic; S.G. $=$ Pcca [54]; $\mathrm{a}_{0}=33.438 \AA$, $\mathrm{b}_{0}=17.425 \AA, \mathrm{c}_{0}=14.112 \AA ; \mathrm{MAC}=128.89(\mathrm{CuK \alpha}) ; \mathrm{D}_{\mathrm{x}}=4.863 \mathrm{~g} \mathrm{~cm}^{-3} ; \mathrm{Z}=8 ; \mathrm{V}=8222.46 \AA$ ; ; Internal standard: $\mathrm{Si}$ )

\begin{tabular}{|l|l|l|l|l|l|l|}
\hline Nr. & $\mathrm{d} / \AA$ & $2 \theta /{ }^{\circ}$ & $\begin{array}{c}\text { Rel. Int./ } \\
\%\end{array}$ & $\mathrm{~h}$ & $\mathrm{k}$ & $\mathrm{l}$ \\
\hline 1 & 10.420 & 8.485 & 4.2 & 1 & 1 & 1 \\
\hline 2 & 9.170 & 9.645 & 100.0 & 2 & 1 & 1 \\
\hline 3 & 8.712 & 10.153 & 14.6 & 0 & 2 & 0 \\
\hline 4 & 8.359 & 10.583 & 10.8 & 4 & 0 & 0 \\
\hline 5 & 7.817 & 11.319 & 0.6 & 3 & 1 & 1 \\
\hline 6 & 7.537 & 11.742 & 0.7 & 4 & 1 & 0 \\
\hline 7 & 7.238 & 12.229 & 0.3 & 1 & 2 & 1 \\
\hline 8 & 6.777 & 13.064 & 0.7 & 2 & 2 & 1 \\
\hline 9 & 6.648 & 13.318 & 0.2 & 4 & 1 & 1 \\
\hline 10 & 6.501 & 13.622 & 1.0 & 2 & 0 & 2 \\
\hline 11 & 6.173 & 14.349 & 0.5 & 3 & 2 & 1 \\
\hline 12 & 6.091 & 14.543 & 2.0 & 2 & 1 & 2 \\
\hline 13 & 6.032 & 14.686 & 3.4 & 4 & 2 & 0 \\
\hline 14 & 5.710 & 15.520 & 3.5 & 5 & 1 & 1 \\
\hline 15 & 5.641 & 15.711 & 3.7 & 3 & 1 & 2 \\
\hline 16 & 5.547 & 15.979 & 2.7 & 4 & 2 & 1 \\
\hline 17 & 5.487 & 16.155 & 6.6 & 2 & 3 & 0 \\
\hline 18 & 5.392 & 16.440 & 17.5 & 4 & 0 & 2 \\
\hline 19 & 5.303 & 16.718 & 4.2 & 1 & 3 & 1 \\
\hline 20 & 5.210 & 17.018 & 2.2 & 2 & 2 & 2 \\
\hline 21 & 5.114 & 17.342 & 22.5 & 2 & 3 & 1 \\
\hline 22 & 4.968 & 17.853 & 27.3 & 6 & 1 & 1 \\
\hline & & & & & & \\
\hline 19 & & & 1 \\
\hline
\end{tabular}

\begin{tabular}{|l|l|l|l|l|l|l|}
\hline $\mathrm{Nr}$. & $\mathrm{d} / \mathrm{A}^{\circ}$ & $2 \theta /{ }^{\circ}$ & $\begin{array}{c}\text { Rel. Int./ } \\
\%\end{array}$ & $\mathrm{~h}$ & $\mathrm{k}$ & $\mathrm{l}$ \\
\hline 51 & 3.322 & 26.841 & 5.0 & 9 & 2 & 1 \\
\hline 52 & 3.303 & 26.999 & 13.1 & 3 & 1 & 4 \\
\hline 53 & 3.242 & 27.513 & 4.5 & 5 & 4 & 2 \\
\hline 54 & 3.237 & 27.552 & 1.0 & 3 & 5 & 1 \\
\hline 55 & 3.230 & 27.613 & 4.0 & 9 & 1 & 2 \\
\hline 56 & 3.209 & 27.799 & 5.0 & 2 & 2 & 4 \\
\hline 57 & 3.195 & 27.923 & 19.0 & 4 & 1 & 4 \\
\hline 58 & 3.182 & 28.045 & 14.0 & 1 & 4 & 3 \\
\hline 59 & 3.138 & 28.442 & 12.3 & 7 & 4 & 1 \\
\hline 60 & 3.120 & 28.607 & 6.0 & 5 & 0 & 4 \\
\hline 61 & 3.111 & 28.695 & 3.0 & 1 & 5 & 2 \\
\hline 62 & 3.086 & 28.930 & 4.0 & 6 & 4 & 2 \\
\hline 63 & 3.072 & 29.064 & 5.5 & 3 & 4 & 3 \\
\hline 64 & 3.057 & 29.217 & 12.4 & 6 & 3 & 3 \\
\hline 65 & 3.048 & 29.301 & 5.0 & 10 & 2 & 1 \\
\hline 66 & 3.019 & 29.590 & 2.0 & 5 & 5 & 1 \\
\hline 67 & 2.977 & 30.015 & 2.0 & 10 & 1 & 2 \\
\hline 68 & 2.938 & 30.428 & 2.8 & 5 & 2 & 4 \\
\hline 69 & 2.928 & 30.526 & 3.4 & 7 & 4 & 2 \\
\hline 70 & 2.911 & 30.717 & 3.2 & 3 & 3 & 4 \\
\hline 71 & 2.839 & 31.517 & 18.8 & 10 & 3 & 1 \\
\hline 72 & 2.831 & 31.606 & 8.0 & 5 & 5 & 2 \\
\hline
\end{tabular}




\begin{tabular}{|l|l|l|l|l|l|l|}
\hline 23 & 4.920 & 18.029 & 2.1 & 3 & 2 & 2 \\
\hline 24 & 4.854 & 18.278 & 1.9 & 5 & 0 & 2 \\
\hline 25 & 4.770 & 18.602 & 0.4 & 4 & 3 & 0 \\
\hline 26 & 4.585 & 19.360 & 15.6 & 4 & 2 & 2 \\
\hline 27 & 4.500 & 19.728 & 1.6 & 1 & 1 & 3 \\
\hline 28 & 4.445 & 19.977 & 9.6 & 1 & 3 & 2 \\
\hline 29 & 4.383 & 20.263 & 15.4 & 2 & 1 & 3 \\
\hline 30 & 4.356 & 20.387 & 8.3 & 0 & 4 & 0 \\
\hline 31 & 4.206 & 21.125 & 5.4 & 3 & 1 & 3 \\
\hline 32 & 4.188 & 21.216 & 11.0 & 5 & 3 & 1 \\
\hline 33 & 4.131 & 21.514 & 0.8 & 1 & 4 & 1 \\
\hline 34 & 4.064 & 21.868 & 6.3 & 8 & 1 & 0 \\
\hline 35 & 4.015 & 22.138 & 4.1 & 7 & 2 & 1 \\
\hline 36 & 3.991 & 22.278 & 3.6 & 4 & 1 & 3 \\
\hline 37 & 3.952 & 22.500 & 6.5 & 4 & 3 & 2 \\
\hline 38 & 3.899 & 22.806 & 1.9 & 3 & 4 & 1 \\
\hline 39 & 3.863 & 23.022 & 10.1 & 4 & 4 & 0 \\
\hline 40 & 3.769 & 23.609 & 3.3 & 8 & 2 & 0 \\
\hline 41 & 3.725 & 23.892 & 7.3 & 5 & 3 & 2 \\
\hline 42 & 3.709 & 23.991 & 3.0 & 4 & 2 & 3 \\
\hline 43 & 3.684 & 24.157 & 2.4 & 1 & 4 & 2 \\
\hline 44 & 3.596 & 24.758 & 9.6 & 8 & 0 & 2 \\
\hline 45 & 3.571 & 24.934 & 11.3 & 2 & 3 & 3 \\
\hline 46 & 3.534 & 25.202 & 5.3 & 5 & 4 & 1 \\
\hline 47 & 3.522 & 25.288 & 9.3 & 8 & 1 & 2 \\
\hline 48 & 3.389 & 26.301 & 10.9 & 4 & 4 & 2 \\
\hline 49 & 3.364 & 26.500 & 2.0 & 3 & 0 & 4 \\
\hline 50 & 3.335 & 26.732 & 5.5 & 6 & 4 & 1 \\
\hline
\end{tabular}

\begin{tabular}{|l|l|l|l|l|l|l|}
\hline 73 & 2.813 & 31.817 & 7.6 & 11 & 2 & 1 \\
\hline 74 & 2.804 & 31.914 & 3.0 & 2 & 6 & 1 \\
\hline 75 & 2.792 & 32.061 & 3.5 & 11 & 0 & 2 \\
\hline 76 & 2.761 & 32.428 & 13.5 & 7 & 5 & 1 \\
\hline 77 & 2.757 & 32.481 & 5.0 & 11 & 1 & 2 \\
\hline 78 & 2.725 & 32.862 & 1.5 & 6 & 5 & 2 \\
\hline 79 & 2.706 & 33.111 & 2.4 & 2 & 4 & 4 \\
\hline 80 & 2.696 & 33.232 & 2.0 & 8 & 0 & 4 \\
\hline 81 & 2.686 & 33.364 & 4.2 & 0 & 6 & 2 \\
\hline 82 & 2.681 & 33.428 & 3.0 & 10 & 3 & 2 \\
\hline 83 & 2.664 & 33.639 & 2.9 & 8 & 1 & 4 \\
\hline 84 & 2.655 & 33.757 & 8.0 & 4 & 5 & 3 \\
\hline 85 & 2.652 & 33.793 & 5.0 & 10 & 4 & 0 \\
\hline 86 & 2.624 & 34.170 & 6.3 & 9 & 4 & 2 \\
\hline 87 & 2.618 & 34.257 & 5.3 & 5 & 6 & 1 \\
\hline 88 & 2.610 & 34.355 & 7.0 & 3 & 2 & 5 \\
\hline 89 & 2.601 & 34.481 & 4.5 & 10 & 2 & 3 \\
\hline 90 & 2.575 & 34.836 & 2.5 & 6 & 6 & 0 \\
\hline 91 & 2.564 & 35.003 & 2.6 & 12 & 1 & 2 \\
\hline 92 & 2.558 & 35.076 & 2.5 & 9 & 0 & 4 \\
\hline 93 & 2.550 & 35.197 & 2.3 & 7 & 3 & 4 \\
\hline 94 & 2.531 & 35.465 & 1.8 & 9 & 1 & 4 \\
\hline 95 & 2.516 & 35.683 & 6.6 & 11 & 3 & 2 \\
\hline 96 & 2.512 & 35.740 & 3.5 & 12 & 3 & 0 \\
\hline 97 & 2.492 & 36.046 & 8.3 & 5 & 2 & 5 \\
\hline 98 & 2.484 & 36.160 & 2.0 & 12 & 2 & 2 \\
\hline 99 & 2.473 & 36.335 & 4.6 & 1 & 5 & 4 \\
\hline 100 & 2.464 & 36.459 & 4.8 & 1 & 6 & 3 \\
\hline
\end{tabular}

Figures 

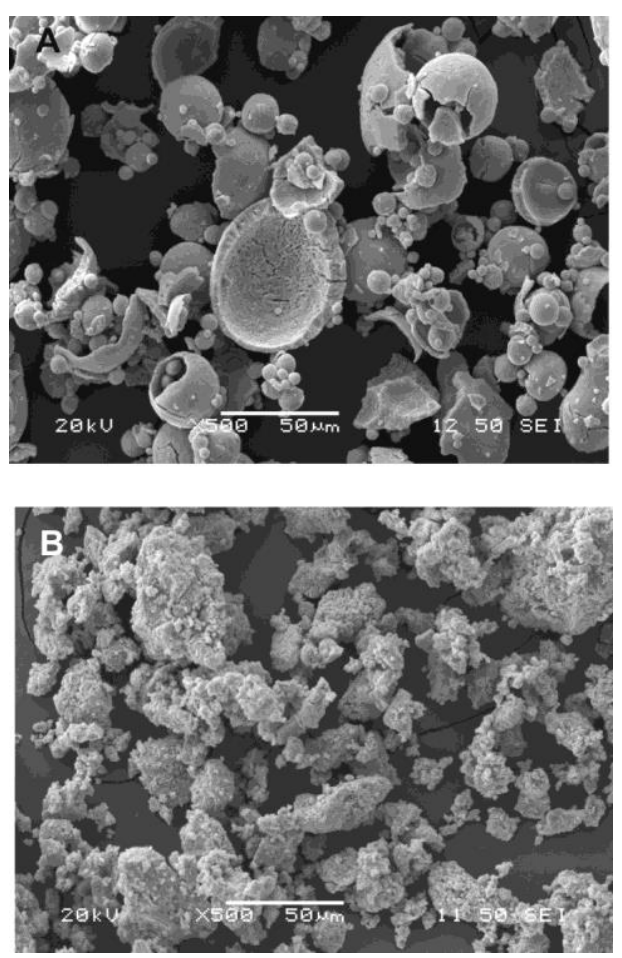

Figure 1. SEM images of (a) AMT1 and (b) AMT2

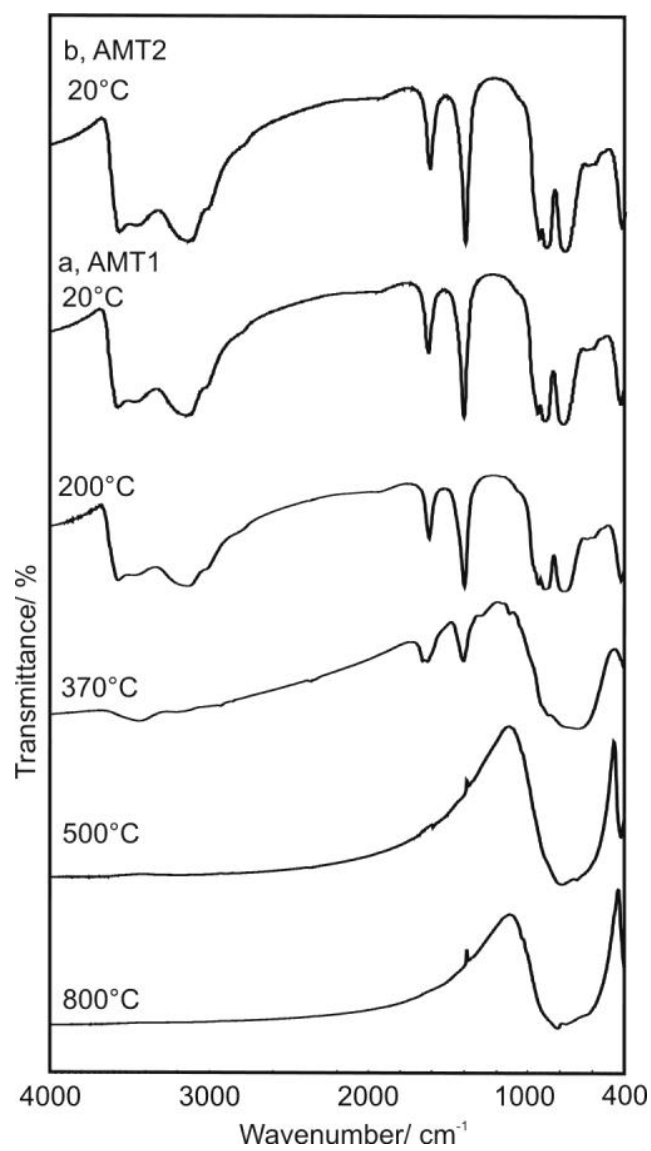

Figure 2. FTIR spectra of (a) AMT1 and its thermal decomposition products in nitrogen and (b) AMT2 


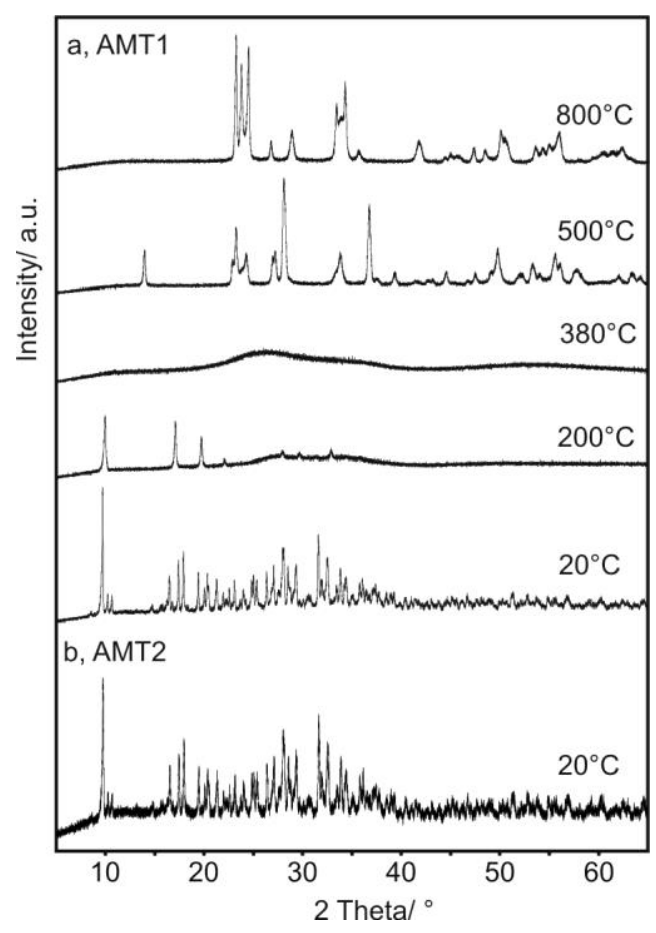

Figure 3. XRD patterns of (a) AMT1 and its thermal decomposition products in nitrogen and (b) AMT2

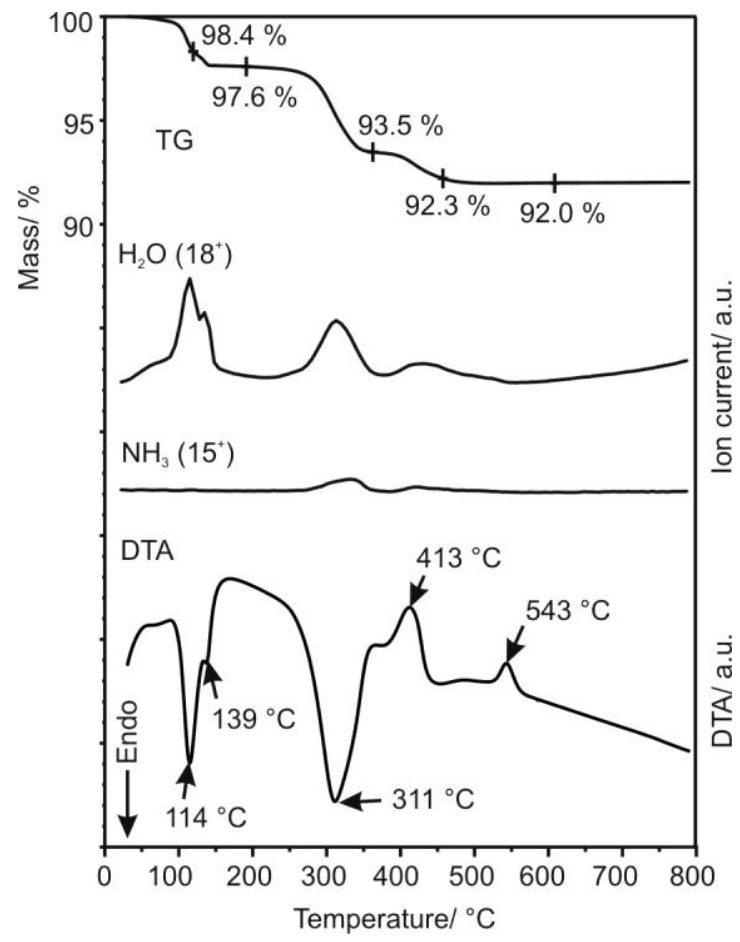

Figure 4. TG/DTA and evolved gas analytical MS ion current curves of the thermal decomposition of AMT1 in nitrogen 


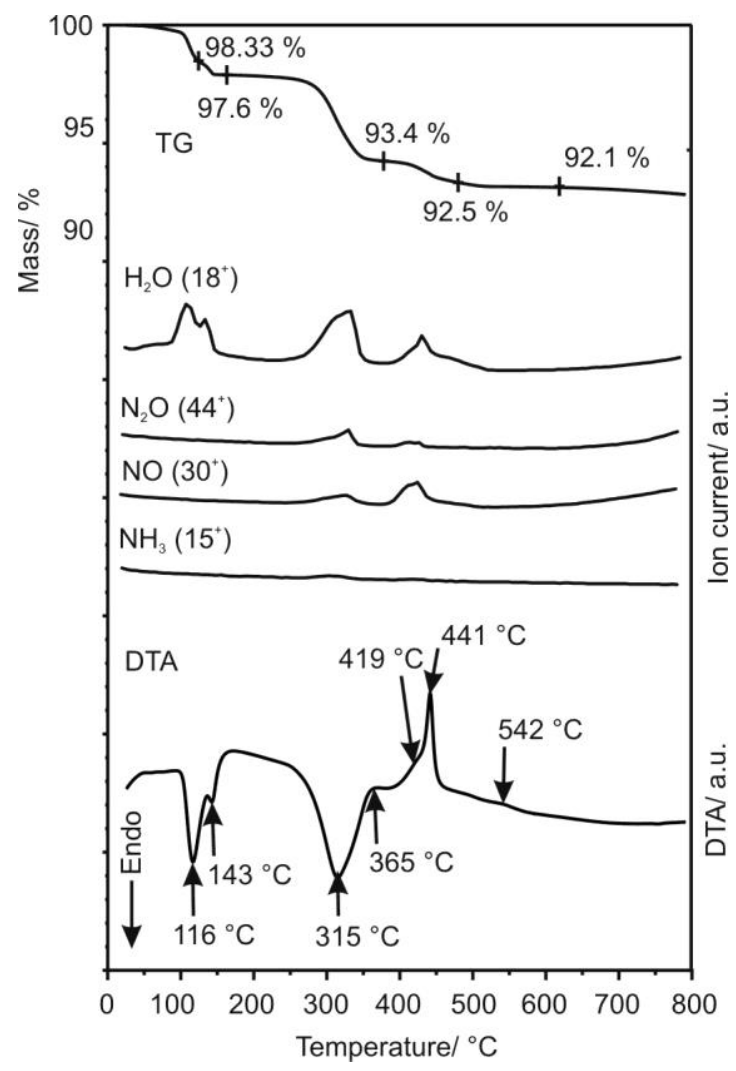

Figure 5. TG/DTA and evolved gas analytical MS ion current curves of the thermal decomposition of AMT1 in air

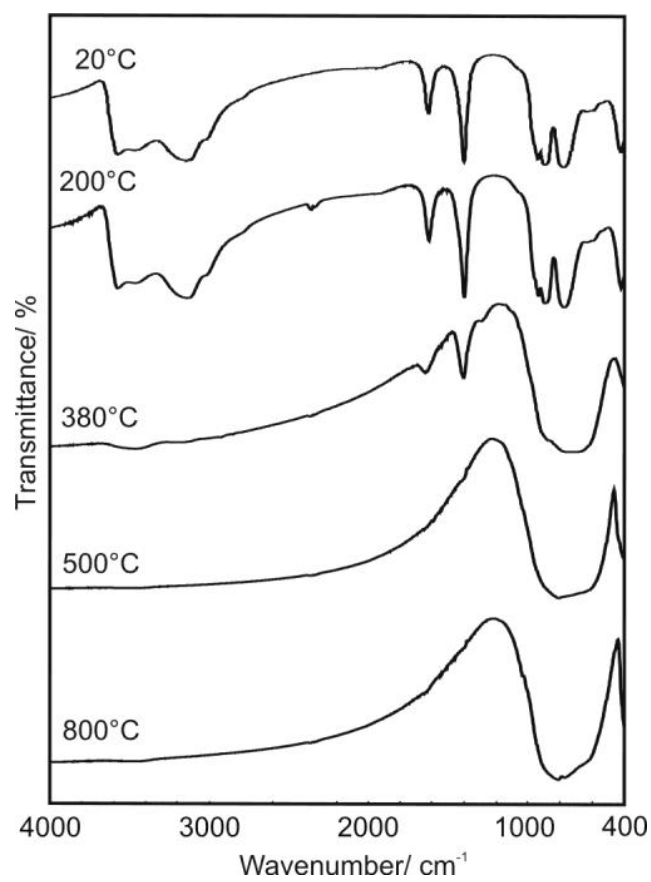

Figure 6. FTIR spectra of the thermal decomposition products of AMT1 in air 


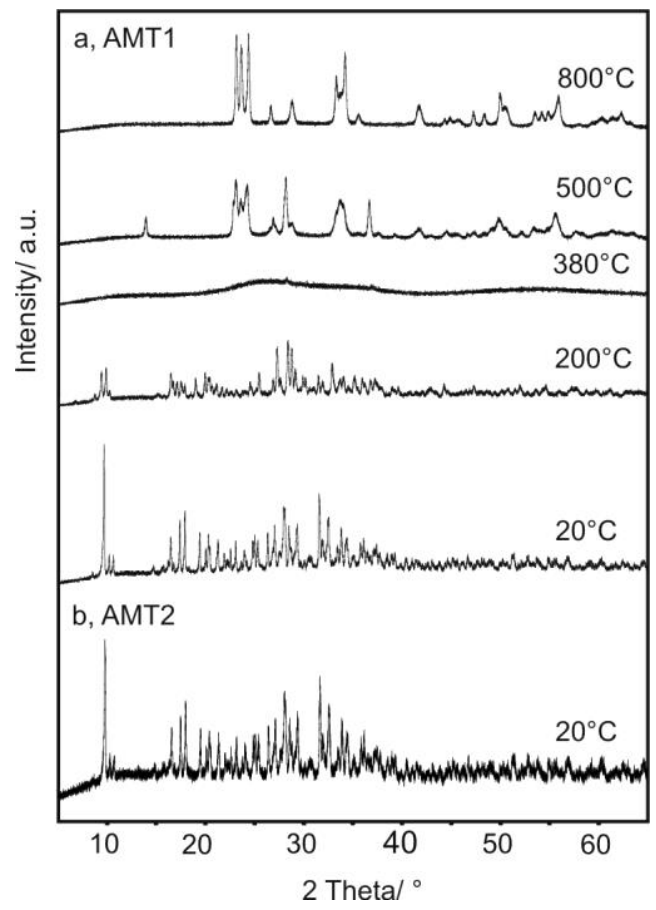

Figure 7. XRD patterns of the thermal decomposition products of AMT1 in air

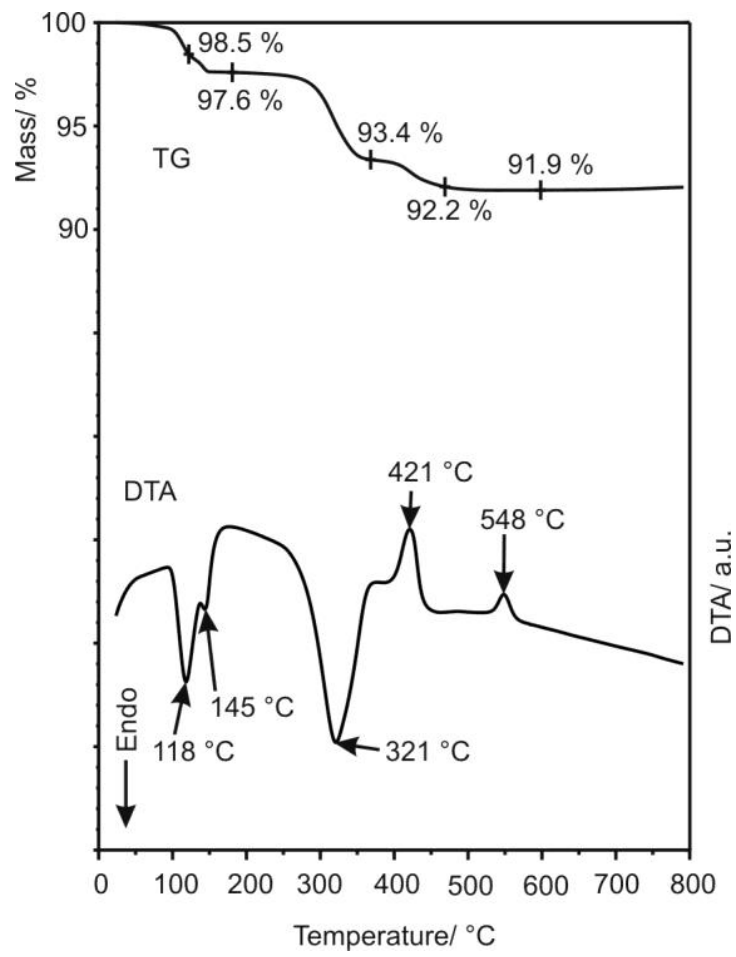

Figure 8. TG/DTA curves of the thermal decomposition of AMT2 in nitrogen 